\title{
AN IDEAL HUSBAND, OR AN IDEAL WIFE? THAT IS THE QUESTION
}

\author{
Mahsa Zayani, Shiraz University, Iran \\ Farideh Pourgiv, Shiraz University, Iran
}

\begin{abstract}
To the modern reader, the Nineteenth Century England has always been the reminiscent of unrelenting ideals regarding social codes of conduct. Although such ideals have been widely criticized, they were passed off as unquestionably natural and necessary to be carried out during the Victorian era. Yet Oscar Wilde, the renowned dramatist of the time, was one of the authors who dared to put to challenge the accepted prescribed gender roles exposing their constructed essence using his insurmountable wit. The current article aims at analysing the apparently transgressive gender roles in Oscar Wilde's play; An Ideal Husband, with the aid of Judith Butler's theory of performativity, a theory which disavows the concept of an inherent gender identity in favour of the idea that gendered behaviours are the consequence of performing certain discursively assigned acts.
\end{abstract}

Keywords:The Victorian era, Oscar Wilde, Judith Butler, Gender Roles, Gender Identity, An Ideal Husband.

Well-known for its breath-taking haste towards development, the Nineteenth Century England is an age of wonders, an age whose rapid changes have ever since bewildered those who take an interest in turning over the pages of its history. Taking tremendous steps towards industrialization, in the blink of an eye England made itself the reputation of the greatest world power. Fast railways, telegraph, iron ships, photography and anaesthetics are but a few of its claim to success; not to mention the astonishing pace with which it lay hands on a great many countries and the expansion of its borders through the then flattering and well-deserved practice of colonization.

Although it is evident that the early twentieth century critics showed unrelenting antagonism to the Victorian lifestyle and strived to prove their mentality as absurd and prudent, the nineteenth century English citizens were pretty much assured that they were living in a Golden age of progress in the history of human civilization. The confidence gained by the virtue of such advancements made Victoria's subject wonder if there really existed a problem whose solution had the ability to put the Victorians in despair.

However, at the primary levels of its emergence, the rush towards industrialization suffered dark pitfalls just as well as enjoying the radiance of glory. The rapid change to modernization forced the working class to leave the rural scenes of England and swarm to the cities to seek jobs in new factories instead which in turn brought about a widespread unemployment of those relying on manual jobs to earn a living and the new economic philosophy of laissez-fair which saw the elimination of governmentfrom regulating the working conditions profitable added but more insult to the injury.

Yet passing through this early phase of the Victorian era which is remembered as the Time of Troubles, England met with relative social prosperity in the years to come. The industrial and the economic situations were improved and the harsh working conditions of 
the poor alleviated and England more assuredly got to boast of and celebrate the bright sides of the rapid changes that it took pains to go through. The achievements of this marvellous development were put to public view by Prince Albert in the Great Exhibition of modern industry and science in 1851. The modernization that the Victorian era stepped into at such a high pace so greatly altered its scenery to the extent that if a Victorian had the chance to look back at it could not help but become bewildered at the turn of events.

Despite the fact that this era is reputed for not allowing any shackles to chain its exhilarating technological and scientific advancements, yet it did not realize how to put up with any sort of deviation from traditionally prescribed gender roles either. Reluctance on the part of this era's subjects to practice these roles was deemed eccentric and its stifling worthy of the effort. In other words, both male and female subjects were required to conform to a set of strict codes of behaviour the reversal of which the society was unwilling to take in stride.

Men and women were required to tread on the path laid by their cultural codes before them which was unique for each sex and not to intrude in the sphere specific to the other sex or they would, at a lofty price, face the hostility of their society. Lord Alfred, Tennyson, the highly revered poet laureate of the century, pinpoints the hallowed distinction in his narrative poem Princess and speaks out his time's ideals as such:

Man for the field and woman for the hearth:

Man for the sword and for the needle she:

Man with the head and woman with the heart:

Man to command and woman to obey (2016: 427-430).

Even if a woman found herself plagued with a dire economic situation and not lucky enough to be secured by marriage, the only respectable position for her to cling to was that of a governess; an unmarried woman living on small wages by teaching the children of the household, a precarious position widely explored by the novelists of the era and once again amounting to nothing more cerebral than the role of a caregiver.

Having for long been accustomed to the double male/female standards, a Victorian woman aspired for no more than trivial accomplishments and rudimentary education. Ruling out the possibility of holding office for a woman, seeking a profitable marriage and looking forward to doing the domestic duties which came as its natural result, was the rule of the day. A woman was by no means expected to "aspire to be her husband's intellectual companion, but rather to amuse his leisure hours [...] and look after his person and his house, freeing and refreshing him for more important things" (Ruse 1993: 886).

However incessantly regulated so as not to lose its naturalized effects, the Victorian hegemony was sure to come face to face with those subjects who challenged its structure and created their own set of beliefs. John Stuart Mill, a contemporary liberalist philosopher,who was an advocate of the freedom of opinion and expression, sees the stifling of opinions against the mental well-being of mankind. According to Mill, suppressing an idea was a gross mistake since that idea may represent the truth and to simply deny this is to fall into an even bigger error of assuming "our own infallibility" (1975: 65). 
Besides, even if the opinion is proven to be an error, nevertheless it should be allowed the opportunity of expression since it is possible for that it holds within itself "a portion of truth; and since the general or prevailing opinion in any subject is rarely or never the whole truth, it is only by the collision of adverse opinions that the remainder of the truth has any chance of being supplied." If mankind, Mill believes, is deprived of his/her right to the freedom of expression and if dogma or prejudice rules the social scene, that society should not be expected to witness "the growth of any real and heartfelt conviction, from reason or personal experience" (1975: 65).

Born in 1854 in Dublin, Oscar Wilde is another intellectual figure who dared to oppose the Victorian ideology both in words and action. Wilde can be safely put on the opposite pole of the social spectrum from Lord Alfred Tennyson, the latter being the spokesperson of the ideals of his time, one whose In Memoriam was what his sovereign sought when in need of consolation, while the New York Times entitled the former as "the laureate of beauty" (1882) whose stern individualism led him to believe that "[a]n ethical sympathy in an artist is an unpardonable mannerism of style" (Wilde 2008: 3).

An advocate of the Aesthetic Movement of the late nineteenth century, Wilde, as an author, did not acknowledge having a moral duty to his society and instead adopted a philosophy which regarded the creation of art as a supreme end in itself. His tendency to look at art as a source of sensual pleasure and his disavowal of the didactic literature were characteristics of the philosophy of Art for Art's Sake which gave value to the social detachment of the artist and his/her subjective concerns. As Murrenus says of Wilde, "[r] arely have we 'read' such outré and flamboyant style, whether in fashion or in letters, as that of the irrepressible Oscar Wilde, as subversion, rebellion against 'normalcy,' and as an indictment against intolerance" (2001: 156).

A flamboyant figure in this movement, Wilde's devotion to this new hedonism placed him counter to his society and what was belied to be an artist's responsibility towards it. Such devotion prompts Lord Henry Wotton, one of the characters from his novel The Picture of Dorian Gray and one who is believed to be the mouthpiece for Wilde himself, to say that: "To be good is to be in harmony with one's self, [whereas] discord is to be forced to be in harmony with others" (2008: 67-68).

Not only did Wilde not seek to be in harmony with the mainstream of his society and give a hand in propagating its standards, but he also never failed to make fun of its superficial tendencies. He realized the values that his society kept imposing on its subjects as utterly artificial and tools of domination in the hands of some to rule over others; the values over which his people agonized since they were dubbed essential in leading a respectable life in keeping with the most idealistic and well-developed civilization in the world.

As a critique of social affairs, Wilde pinpoints the destructive sides of scientific and technological advancements in a modern setting as well as its enlightening aspects. The objective observations of science, for instance, and the ways of understanding that it offered collaborated in the domination of certain oppressive and by no means natural ideologies. Furthermore, the ambitious terms of freedom and individualism which the modern society boasted of were exploited to conceal the inequalities and bury its vices of injustice out of sight and under the grounds of apparent righteousness. 
Therefore, freedom would be nothing more than a shadow reflected by make-believe puppet of equality hindering individualism's coming to life. The legitimation of values did not stop Wilde in refusing to believe the 'self' as a rational indubitable being, but a social construct and a by-product of language loaded with ideology which unconsciously thrived in shaping people's thoughts and endorsing the repressive state apparatus. The identity, therefore, cannot be analysed separately from the context of one's life since everyone inherits his/her definition of the self from their cultural milieu (Gagnier1997: 19-20).

Considering that freedom was too great and immature a demand to make of Wilde's society, in his literary career he insisted on unaccountability for what he presented in his art probably in hope of covering his ideological transgressions. Wilde warned his audience against an autobiographical reading of his works which he put to words in the preface of his novel as: "To reveal art and conceal the artist is art's aim" (2008: 3). Yet such a claim did not rush to his rescue during his trials at the court of law where his art was used against him to prove his "perverted moral views" (qtd. in Hyde 1973: 110) and sped his fall from public favour and ultimately his deplorable lonely death in France due to committing an act of "gross indecency" (Cohen 1997: 529) or better to say an act of "gross movement against social tolerability."

The death of Wilde, however, never meant the death of such fundamental question as gender identity. The twentieth century, especially the latter part, witnessed the raising voice of the feminists and those who were not daunted to put this question to open discussion and boldly challenge it. Judith Butler, the American philosopher and feminist theorist, is an audacious example. In her book, Gender Trouble, she mainly deals with a criticism of the naturalized coherence of the categories of sex, gender and sexuality which, she believes, are culturally and discursively constituted through time.

Butler's purpose, she herself emphasizes, must not be construed as prescribing a new model for gender, but rather to "open up the field of possibility for gender without dictating which kinds of possibilities ought to be realized."The book, hence, is a lot congenial to the experience of those who have understood "what it is to live in the social world as what is 'impossible', illegible, unrealizable, unreal, and, illegitimate" (1999: VIII).

The book seeks to disclose habitual presumptions which render juridically instituted identities possible and nevertheless, put to margin the subjects who transgress it and make them a sort of unthinkable panic through which it is enabled to maintain its regulatory force. Butler assures the reader that there is absolutely no position to be found outside the field of power, yet the social misfits are the potential agents of interruption within regulatory regimes. She also maintains: "[t]hose who are deemed 'unreal' nevertheless lay hold of the real, a laying hold that happens in concert, and a vital instability is produced by performative surprise" (1999: XXVI). Thus, an attempt to make possible a liveable life for those hitherto repressed gender identities becomes the ultimate aim of Butler's pivotal book Gender Trouble.

Butler believes that sex should not be interpreted as a pre-cultural component in the construction of identity. In her politics there is no "prior", "before" or outside since it is counterfeited by various discourses serving different social and political interests and succeeds to defraud us by veiling its cultural designation. Our bodies and therefore our identities do not stand outside culture; rather culture processes and forms them. Yet in 
no way it should be understood that our bodies are the passive tablets on which culture inscribes its codes; rather they contribute to the formation of our identity through the performance of a set of acts which are either interpreted as conforming to the gender of its doer or in opposition to it. This concept Butler calls 'performativity.'

In Butler's words, the performativity of gender suggests that:

[Gender] has no ontological status apart from the various acts which constitute its reality. This also suggests that if that reality is fabricated as an interior essence, the varying interiority is an effect and function of a decidedly public and social discourse, the public regulation of fantasy through the surface politics of the body. [...] in other words, acts and gestures, articulated and enacted desires create the illusion of an interior and organizing gender core, an illusion discursively maintained for the purpose of [...] regulation. (1999:

Repeating gender acts over and over again, the subjects tacitly legitimize them and allow them to give way to an illusion of real man or woman among other social fictions. The sedimentation of gender norms, therefore, produces certain agreeable corporeal styles which if contested would result in the exclusion of the transgressive performer from social and cultural recognition in order to secure the natural order. So, acting gender is in essence a social drama which requires the re-enactment of gender norms to be able to survive (Butler 1999: 178).

Gender, Butler emphasizes, must not be thought of as a stable locus of agency to which one could associate certain acts, but it is "an identity tenuously constituted in time, instituted in an exterior space through a stylized repetition of acts. [It] is produced through the stylization of the body and, hence, must be understood as the mundane way in which bodily gestures, movements, and styles of various kinds constitute the illusion of an abiding gendered self"' (1999: 179).

If gender proves to be no more than the performance of certain acts, then, the appearance of substance is likewise a construction or a performative identity which the subjects themselves come to believe in and deem necessary to follow in order to be counted as recognizable and be able to function in their social order. However, since the gender norms are phantasmatic and a form of superficial signification, it can never be fully internalized or produce an absolute seamless coherence and the partial success it receives is due to a gender corporealization of time, a repetition of acts which aim at realizing the prescribed grounds of identity. But the problem occurs when occasional discontinuities show up and demonstrate identity as baseless and the arbitrary relation between act and gender witnessed in parodic performances or failures in repeating the naturalized a token which makes gender transformation possible (Butler 1999: 179).

Howbeit, it must be emphasized that the possibility of such a transformation does not make it immune from punishments. Propagating the idea that sex and gender are causal unities and therefore both natural and crucial, the power regime constantly makes sure that its subjects believed in such unities and accordingly repeat the ideal gender performance 
so as not to lose sight of its illusory interiority. Therefore, the subjects who do not carry out what the prevailing hegemony requires from them must duly await punitive consequences which keep the rest of the subjects away from committing gender transgression. If such punitive consequences were removed, one would more easily understand that an abiding masculinity or femininity does not exist and as a result no right or wrong when it comes to the issue of gender identity. Such punitive consequences ensuring the juridically desired illusion of gender reality finds proof when analysing Wilde's comedy, An Ideal Husband.

Wilde started writing his comedy, An Ideal Husband, in 1893. As one of Wilde's masterpieces, the play revolves around moral and political corruption as well as public versus private spheres of life. The play was staged in 1895 and proved to be an immediate success being performed one hundred twenty four times after its opening on January 3. However, soon after Wilde was arrested for his act of "gross indecency" and consequently his name as the author got removed from the play.

An Ideal Husband opens at Mr. Chiltern's house. He is an outstanding member of the House of Commons. Mrs.Cheveley, a schoolmate of Sir Robert Chiltern's wife, attempts to blackmail him due to the fact that he sold a secret of the cabinet to Mrs.Cheveley's lover, Baron Arnheim, telling him to buy stocks in Suez Canal before the British government buys it. Having become rich by selling this secret, Sir Robert is forced to support Mrs. Cheveley to build a canal in Argentina if he does not want to lose his reputation both in the world of politics and more importantly with his wife who has put him on a great pedestal and thinks so highly of him. However, Lord Goring, a very close friend of Sir Robert's, comes to the rescue by exchanging the letter which proves Chiltern's crime with not having Mrs.Cheveley arrested for stealing a diamond brooch which Lord Goring came upon in his friend's party. He also manages to persuade Lady Chiltern to be less morally strict and forgive her husband to save the marriage. The play meets a happy ending with the dandified rescuer, Lord Goring, marrying his best friend's sister; Mabel Chiltern.

Act one begins with introducing Lady Chiltern, the hostess of the party, to the audience. As an idealistic Victorian woman, physically as well as personally, one whose characteristics comply with patriarchal demands, she is described as "a woman of grave Greek beauty" standing close to the significant "eighteen century French tapestryrepresenting the Triumph of Love, from a design by Boucher" (Wilde 2005: 1) looming large since it is emblematic of the great sacrifice she makes at the end of the play for the sake of saving her compromising marriage.

Together with Sir Robert, Lady Chiltern is hosting a party held for the prestigious members of London society. Yet as highly thought of members of society, not all of them represent the idealistic attitudes of the Victorian era and not caring to pose as the paragons whom other subjects should follow for playing their expected social roles. Lord Caversham, an old-fashioned well-respected character in the play, enters the party looking for his "good-for-nothing young son" whom he calls so on the basis that "he leads such an idle life" (Wilde 2005: 2).

Lord Caversham's son, Lord Goring, is an example of the dandified character in Wilde's comedies and the reason his father refuses to give him credit. As a dandy, Lord Goring possesses an eccentric figure unconcerned about the masculine role he is expected to play and is given to leisurely hobbies the most prominent of which is his occupation with 
flamboyant clothes. As a subject living in the Victorian era with its demanding codes of conduct, he seems to very much embody the description Albert Camus offers for such a character as his:

The dandy is, by occupation, always in opposition. He can only exist by defiance. [...] he finds himself delivered over to the fleeting moment, to the passing days, and to wasted sensibility. The dandy rallies his forces and creates a unity for himself by the very violence of his refusal. (2012: 51)

The dandy's transgression from prescribed gender roles results in his being regarded as eccentric and his behavior, not following a proper enactment of masculinity, as effeminate since there is no other recognized gender in the paternal law to fall in between. An oldfashioned conventional man of the Victorian era, Lord Caversham has reason enough to constantly disapprove of his son's conducts because he has chosen not to adopt gender politics perform his gender. In other words, through his dandified character, Lord Goring puts in display the fact that "the essence or identity that [gender acts] purport to express are fabrications" which he refuses to conform to through "corporeal signs" (Butler 1999: 173).

Lord Goring's dandyism, however, does not repel everyone as it does his father. Mabel Chiltern, Sir Robert's sister, is not only not stove off by his gender transgression, but she is on the contrary very much attracted by it. She contests Lord Caversham's belief that his son has given way to an idle life-style saying that he "rides at the Row in ten o'clock in the morning, he goes to the Opera three times a week, changes his clothes at least five times a day and dines out every night of the season. You don't call that an idle life, do you?" (Wilde 2005: 10).

A witty and quick-in-comical- response character just as Lord Goring is, Mabel Chiltern also shows signs of transgression from her expected gender identity. She does not mind Lord Goring's effeminacy and is not looking for a prescribed masculinity required from a male Victorian in whose opposition she could find and embody her own assigned feminine identity. She further buttresses this claim in answer to Lord Caversham's feeling who is "[s]ick of London Society." She retorts: "I love London Society! I think it has immensely improved. It is entirely composed now of beautiful idiots and brilliant lunatics. Just what Society should be" (Wilde 2005: 10). Although Mable's response could be read as a satirical comment on the hypocritical nature of the Victorians occupied with trivial and superficial matters, regarding the time setting of the play which is the late Nineteenth Century, her response is more likely to be interpreted as an admiration of the changing ideals in this period and the modern subjects' disavowal from the old strict conventions of morality and unquestionable gender roles might have led the old-fashioned ones, such as Lord Caversham, to believe that the abandonment of such long held values has no explanation other than unforgivable idiocy.

Mabel is not attracted to Tommy Trafford who, according to Lady Chiltern, "is the best secretary [Lord Chiltern] has ever had" (Wilde 2005: 66) with "a brilliant future before him" (Wilde 2005: 67). Contrary to what the society may expect, she refuses to accept the hand of a man who is greatly approved of. She even seems to be repelled by Tommy's 
proposal which he did "in broad daylight in front of [the] dreadful statue of Achilles" who is one of the greatest heroes in Greek mythology and is a perfect epitome of the masculine gender identity (Wilde 2005: 66).

Unconcerned about the ideal of submissiveness and enacting feminine coyness, Mabel feels "free to express her adoration for Lord Goring in a very public way" (Szanter 2014: 7). To some extent, she manages to perform her gender as she prefers not hesitating to give voice to her passion for Lord Goring, an expression which is traditionally thought of as an act which the male party is more naturally to undertake:

I adore you. Everyone in London knows it except you. It is a public scandal the way I adore you. I have been going about for the last six months telling the whole society that I adore you. I wonder you have anything to say to me. I have no character left at all. At least, I feel so happy that I'm quite sure I have no character left at all. (Wilde 2005: 123)

However, Mabel's slight transgression from her assigned identity has not been free from social consequences. Incurring "public scandal" and the fact that she thinks she has "no character left at all" (ibid) are reminiscent of Butler's claim that punishment awaits "those who fail to do their gender right" (1999: 178).

Mabel Chiltern, though, is not the only feminine character in the play who displays signs of gender transgression. Mrs. Cheveley too must be taken into account in this regard and probably even more so. Notoriously active in the world of politics and stepping into the house of Sir Robert Chiltern not as a delicate feminine character trying to entertain herself by roaming about trivial matters, just as Mrs.Marchmont and Lady Basildon comically do, but as one who aims at accomplishing a lucrative mission, her appearance is described in a rather vivid contrast with Lady Chiltern's: "lips very thin and highly coloured, a line of scarlet on a pallid face. Venetian red hair, Aquiline nose, and long throat. Rouge accentuates the natural paleness of her complexion" (Wilde 2005: 11).

Wilde's description of her as such implicitly conveys the sense that her choice of vocation as a political activist, a very highly masculine role for the Victorian era, rather than a typical woman who tends to domestic tasks, is unfavorably reflected in her physical appearance. She lacks the desirable Greek beauty owned by Lady Chiltern and the only feminine features to her "pallid face" have come through the use of heavy make-up. In depicting Ms.Cheveley's appearance, Wilde goes on further to say that "she shows the influence of too many schools" (2005: 11).This description and the fact that she has got an "aquiline nose" seem to match Lady Markby's remark that she makes later on in the play. As a conventional Victorian woman, she claims that: "I think anything is better than high intellectual pressure. That is the most unbecoming thing there is. It makes the nose of the young girls so particularly large. And there is nothing so difficult to marry as a large nose; men don't like them" (Wilde 2005: 36).

If what Lady Markby says is in fact right in the Victorian social discourse and if Mrs. Cheveley's "aquiline nose" and plain appearance are actually the effects of "intellectual pressure" exerted on her due to "the influence of too many schools", then her not being physically favorable, as implicit in Wilde's description, is not the result of her natural 
plainness of appearance, it is actually the kind of response the patriarchal culture illicits towards those women who fail or refuse to act in accord with their normalized gender identity, or as Butler would say, those who refuse to make their actions be seen as " interpretations within the confines of already existing directives" (1998: 526).

It does not matter how hard Mrs. Cheveley tries to emancipate herself from performing just the same gender roles that are imposed on women or how diligently she tries to assert her individuality, she is after all "subject to the same limitations that attend other women in the play, all of whom achieve their goals only through their roles as wives". The brooch which she left in Sir Robert's house represents her "unwitting enslavement to male lovers" or her being trapped in the patriarchal culture in general (Dellamora 1994: 129).

As a woman, Mrs.Cheveley fails to achieve success in her morally compromising mission as easily as Sir Robert does in his more or less the same act. It is noteworthy that, in order for Mrs.Cheveley to substantiate her claim of Sir Robert's betrayal, she has to submit the incriminating correspondence between him and Baron Arnheim. And thus, Lord Goring's burning it literally puts an end to the power that she claimed to possess.

However, while a solid document was needed for Mrs.Cheveley to prove her accusation, Lord Goring's mere words, apparently, suffice if he is to have Mrs.Cheveley arrested. The great possibility that Lord Goring's words, howbeit an effeminate man, will be taken for granted is signified by her grave reaction when he threatens her: she is "in an agony of physical terror. Her face is distorted. Her mouth awry. A mask has fallen from her. She is, for the moment, dreadful to look at" (Wilde 2005: 111). Mrs.Cheveley's mission, therefore, is easily intercepted since as a naturalized characteristic of her gender, the notion of women being untrustworthy is regulated "before [she] arrived on the scene" (Butler 1998: 526). As expected by a patriarchal structure, then, Mrs.Cheveley rightly passes into obscurity since she dared to "invade and undermine the male subject-spectators; by asserting [herself] as creator and subject, [she] disrupt[s] social and cosmic order as well as gender hierarchy" (Dolan 1993: 225).

In contrast to the hitherto discussed female characters that irritated their cultural context in varying degrees by turning their backs on their valued gender roles, Lady Chiltern turns out to be the impeccable embodiment of the Victorian woman, one who Mabel describes as "a noble, self-sacrificing character" (Wilde 2005: 67) and Lady Markby believes to be a paragon for Victorian women. Although the divulgence of Sir Robert's incriminating letter would bring about quite a disaster for his political profession, he is much more concerned about losing the love of his ideal wife. Lady Chiltern conforms to the values of her time to the extent that she seems to be absolutely robbed of her agency and totally paralyzed by the web that patriarchal demands has knitted all over her will power. It is agreed by many critics that such a weakling character that Bernard Shaw called "a stupidly good wife" (1932: 11) could hardly ever exist.

Believed to be capable of setting a good example for all Victorian women, Lady Chiltern's strict reliance upon codes of morality is revealed when she tells Mrs.Cheveley that the past "has taught me that a person who has once been guilty of a dishonest and dishonourable action may be guilty of it a second time, and should be shunned" (Wilde 2005: 77). She refuses to believe one's identity once set as dishonorable could ever be any different. She proves her unrelenting morality in the play in her attitude towards Mrs.Cheveley and her own husband. 
Upon finding out Mrs.Cheveley's request from her husband, Lady Chiltern becomes so distressed lest her ideal husband whom she has always considered perfectly moral just as she is, falls from grace in which case she would not hesitate to decide that it would be better for both of them that their lives drift apart (Wilde 2005: 44). She is so unbelievably serious that Sir Robert refuses to surrender to his wife's pleas for telling her the truth about his past and instead, turns to his dandified friend for help.

Lord Goring's handling of the matter, however, is quite surprising. Contrary to the expectation of those who agree with Lord Caversham that as a man choosing to live the life of a dandy, he is "good-for-nothing" (Wilde 2005: 9), Lord Goring suddenly becomes the voice of reason reproaching his friend both for his past misdeed and being dishonest with his wife. Though his oscillation between an effeminate character not taking life seriously as a man should and the masculine voice of reason, does not stop here. When Lady Chiltern finally understands about Sir Robert's past and goes to Lord Goring for help, he delivers a long speech based on which one would not be able to find the trace of dandyism, but quite the opposite, a fully conventional man given to believing in the patriarchal structure of power asserting the distinction between masculine and feminine gender roles:

Women are not meant to judge us, but to forgive us when we need forgiveness. Pardon, not punishment, is their mission. [...] A man's life is of more value than a woman's. It has larger issues, wider scope, greater ambition. A woman's life revolves in curves of emotions. It is upon lines of intellect that a man's life progresses. [...] A woman who can keep a man's love, and love him in return, has done all the world wants of women, or should want of them. (Wilde 2005: 136)

Through Lord Goring, Wilde deconstructs the idea that gender is immutable. He is recognized as a dandy or a conventional masculine figure redeemed from his effeminacy as long as he performs the attributes of either gender identity, otherwise gender has no essential reality of its own whatsoever. Lord Goring's traditional side of his character might be read, just as well, as symptomatic of the impossibility of total emancipation from the juridical structure of patriarchy.

One may have the chance to go through gender reversal through performing drag, but such an unregulated performativity "is not freedom, but a question of how to work the trap that one is inevitably in" (Butler 2004: 84). Sooner or later the transgressive performer of gender is either pushed back to the constructed and naturalized gender role, more often than not, by being forcefully placed within the recognizable patriarchal structures or by being socially repressed or punished.

Lady Chiltern, on the other hand, does not show as much intention to trespass the required gender identity as do Lord Goring, Mabel Chiltern and Mrs.Cheveley. She claims to never change when it comes to the issue of morality and even tries hard to hold on fast to her beliefs by making Sir Robert write a refusal letter to Mrs.Cheveley's demand, but she relinquishes her principles and decides to forgive Sir Robert to perform the feminine duty her society requires of her, that is, an unwavering and unconditional support of her husband. 
While Lord Chiltern easily justifies his transgression from codes of morality, Lady Chiltern must learn that she is not allowed as much freedom to justify her gender transgression. Sir Robert boldly asks Lord Goring "whom did I wrong by what I did? No one" (Wilde 2005: 49), and even more audaciously claims that he never sensed a twinge of conscience since he "felt that [he] had fought the century with its own weapons, and won" (Wilde 53). Not only is Sir Robert not punished for his immorality, but he also advances in his career receiving "the vacant seat in the cabinet" at the end of the play (Wilde 2005: 132).

Nevertheless, if Lady Chiltern stands firm in her position trying to justify herself the same as her husband does, she would not be just as equally rewarded, but quite the contrary, she would be admonished for trying to place herself in a morally superior position to a man and consequently abandon her duty as a wife by leaving her husband. In other words, Lady Chiltern has to learn that no matter how righteous or idealistic her views are, to her husband she must always be "the white image of all good things" (Wilde 2005:140).

Lady Chiltern's change, thus, if it could be called change at all, is not directed towards expressing her own desire, but it is actually a change in favor of the patriarchal normalization of gendered behavior making her an "ideal wife" whom Sir Robert has to put on pedestal. As Alan Sinfield points out: "Ideology makes sense for us —of us - because it is already proceeding when we arrive in the world" (2004: 745). In order to be entitled to become the "ideal wife", Lady Chiltern lets herself be paralyzed by the ideology of her time allowing the patriarchal discourse make sense of her just as it has always done so to those it accounted as recognizable female subjects.

Although Oscar Wilde named the play An Ideal Husband, not only does it not so much expound upon the factors that may make a man become one, but also the husband that the title refers to turns out to be mistakenly thought highly of since he has concealed his morally compromising past. The play, rather, seems to propagate how a wife should or should not be does she want to be called ideal. However, such an interpretation of the play cannot easily blur the fact that Wilde saw the mutability of gender identity possible and probably even desirable had the characters not lived in a patriarchal world which perpetuated "the illusion of an abiding gendered self' (Butler 1999: 179).

\section{Refrences}

Butler, Judith. 1998. "Performative Acts and Gender Constitution: An essay in Phenomenology and Feminist Theory." Theatre Journal. 40(4): 519-531.

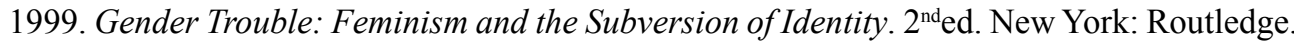
2004. "The Body You Want: Liz Kotz Interviews Judith Butler.” Artforum. 31(3): 82-89.

Camus, Albert. 2012. The Rebel: An Essay on Man in Revolt. Trans. Anthony Bower. New York: Alfred A. Knopf, Inc.

Cohen, William A. 1997. "Gross Indecency: The Three Trials of Oscar Wilde (Review)." Theatre Journal. 49(4): 529-531.

Dellamora, Richard. 1994. "Oscar Wilde, Social Purity, and An Ideal Husband." Modern Drama. 37(1): 120-138.

Dollan, Frances E. 1993. “Taking the Pencil Out of God's Hands: Art, Nature, and the Face-painting Debate in Early Modern England.” PMLA. 108(2): 224-239. Project Muse.Web. 14 Jun 2016. 
Gagnier, Regina. 1997. Wilde and the Victorians. In: Peter Raby (ed.) The Cambridge Companion to Oscar Wilde. Cambridge: Cambridge University Press. 19-20.

Hyde, Harford M. 1973. The Trials of Oscar Wilde. New York: Dover.

Lord Tennyson, Alfred. n. p. The Princess.Bookz.Web. 12 May 2016.

Mill, John Stuart. 1975. Three essays. London: Oxford University Press.

Murrenus, Valerie A. 2001. "Wilde Style: The Plays and Prose of Oscar Wilde (review)." New Hibernia Review. 5(1): 156-157. Project Muse.Web. 20 Aug 2016.

"Phase of English Life." 1882. The New York Times.

Ruse, Michael. 1993. "Will the Real Charles Darwin Please Stand Up?” New Scientist. 100(1): 884-887.

Shaw, Bernard. 1932. Our Theatres in the Nineties. London: Constable.

Sinfield, Allan. 2004. "Cultural Materialism, Othello, and the Politics of Plausibility." In. Julie Rivkin (ed.) Literary Theory: An Anthology. $2^{\text {nd }}$ ed. Malden, MA: Blackwell Pub. 745.

Szanter, Ashley. 2014. “A Silly Girl's Insight: Mabel Chiltern's commentary on Public Versus Private Spheres in An Ideal Husband." The Victorian.2(3): 1-9.

Wilde, Oscar. 2005. An Ideal Husband. San Diego: ICON Group International, Inc. Bookfi. Web. 20 Nov 2015.

—. 2008. The Picture of Dorian Gray. New York: Oxford University Press. 